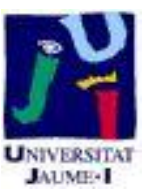

Título artículo / Títol article: Double diastereoselection in anti aldol reactions mediated by dicyclohexylchloroborane between an L-erythrulose derivative and chiral aldehydes

Autores / Autors Díaz Oltra, Santiago ; Ruiz, Purificación ; Falomir, Eva ; Murga, Juan ; Carda Usó, Miguel ; Marco, J. Alberto

Revista:

Organic \& Biomolecular Chemistry (2012) 10(34)

Versión / Versió:

Post-print

Cita bibliográfica / Cita bibliogràfica (ISO 690):
DÍAZ-OLTRA, Santiago, et al. Double diastereoselection in anti aldol reactions mediated by dicyclohexylchloroborane between an l-erythrulose derivative and chiral aldehydes. Organic \& Biomolecular Chemistry, 2012, vol. 10, no 34, p. 6937-6944.

url Repositori UJI: $\quad$ http://hdl.handle.net/10234/69501 


\title{
Double Diastereoselection in Anti Aldol Reactions Mediated by Dicyclohexylchloroborane between An L-Erythrulose Derivative and Chiral Aldehydes $\dagger$
}

\author{
Santiago Díaz-Oltra, ${ }^{a}$ Purificación Ruiz, ${ }^{a}$ Eva Falomir, ${ }^{a}$ Juan Murga, ${ }^{\text {a }}$ Miguel Carda, ${ }^{\text {a }}$ and J. Alberto \\ ${ }_{5}$ Marco* $^{\mathbf{b}}$
}

Received (in $X X X, X X X) X$ th $X X X X X X X X X 200 X$, Accepted Xth $X X X X X X X X X 200 X$

First published on the web $X$ th $X X X X X X X X X 200 X$

DOI: 10.1039/b000000x

The $\operatorname{xxxxx}$.

\section{${ }_{10}$ Introduction}

The aldol reaction is a powerful and general method for the stereocontrolled construction of carbon-carbon bonds. ${ }^{1}$ It may be performed through the use of various types of metal enolates or also in an organocatalytic, metal-free manner.,

15 From the many enolate types investigated thus far, boron enolates have proven to be particularly versatile because of their good reactivity and high stereoselectivity. ${ }^{4}$ In the last decade, we have been investigating the outcome of aldol reactions of boron enolates of protected L-erythrulose 20 derivatives such as $\mathbf{1}$, generated with $\mathrm{Chx}_{2} \mathrm{BCl}$ (dicyclohexylboron chloride). ${ }^{5}$ With these ketones, the latter reagent gives rise to the highly stereoselective formation of syn aldols 2 via the $Z$ enolate $^{6} \mathbf{1}_{\mathbf{B}}$ in reactions with achiral aldehydes RCHO (Scheme 1). ${ }^{7}$
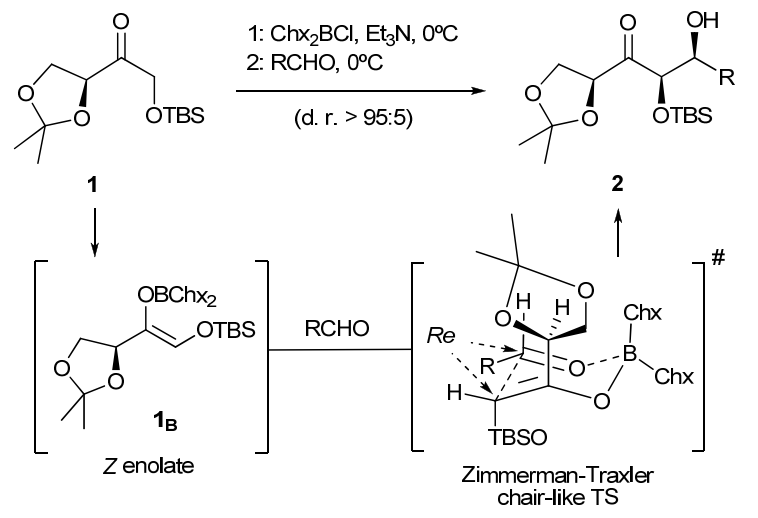

Scheme 1 Aldol additions of a $Z$ boron enolate of chiral ketone 1 to achiral aldehydes via a chair-like transition state (TS) $(\mathrm{Chx}=$ cyclohexyl; TBS = tert-butyldimethylsilyl).

Subsequently to these initial investigations, we wondered 30 whether or not the facial bias of chiral enolate $\mathbf{1}_{\mathbf{B}}$ would be strong enough to overcome the inherent facial preferences of the carbonyl group in aldehydes having a stereocentre in the $\alpha$-carbon atom (double diastereoselection). ${ }^{\text {a-e }}$ Therefore, we investigated the aldol reactions of $\mathbf{1}_{\mathbf{B}}$ with a range of $\alpha$-chiral 35 aldehydes in both antipodal forms. In the initial study, the aldehydes had only carbon substituents ( $\alpha$-methyl aldehydes 3 ) or else one oxygen ( $\alpha$-alkoxy aldehydes 4 ) bound to the $\alpha$ - carbon atom (in all these aldehydes, $\mathrm{P}$ is a protecting group, and $\mathrm{R}$ is a variable fragment). ${ }^{8}$ The study was subsequently 40 extended to the case of $\alpha$-amino and $\alpha$-fluoro aldehydes. ${ }^{9}$ The results of all these aldol reactions are summarized in Scheme 2. The compounds depicted in the Scheme are the only diastereomers detected in the aldol reaction mixture by means of NMR (d.r. > 95:5).

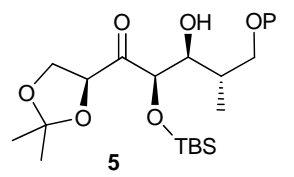<smiles>C[C@@H](C[PH3+])[C@@H](O)[C@H](O[18S])C(=O)[C@@H]1COC(C)(C)O1</smiles>

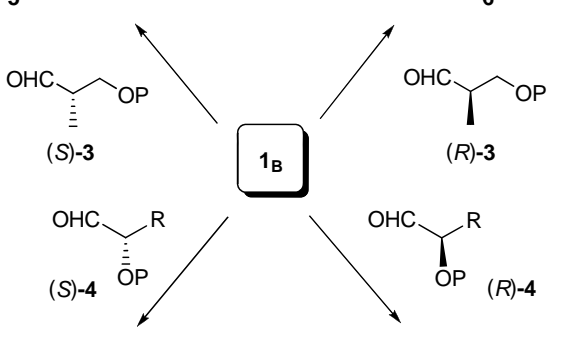

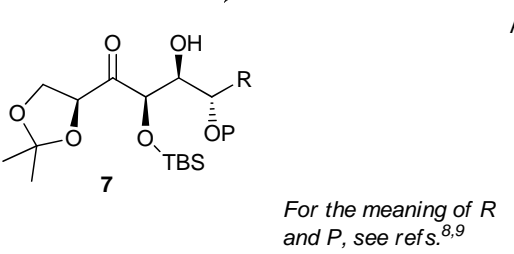<smiles>[R]C(F)[C@H](O)[C@@H](O[13CH3])C(=O)[C@@H]1COC(C)(C)O1</smiles>

Aldol mixture (+ decomp.)
For the meaning of $R$ and $P$, see refs.

10

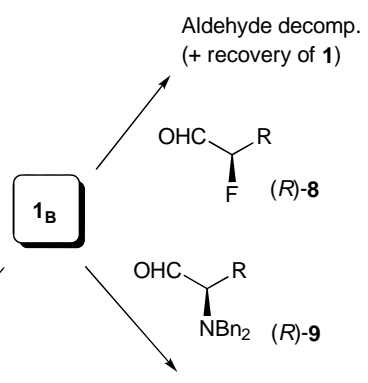

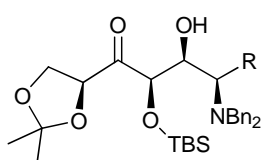

12 
Scheme 2 Aldol additions of enolate $\mathbf{1}_{\mathbf{B}}$ to aldehydes $(R) /(S)$ 3, $(R) /(S)-\mathbf{4},(R) /(S)-8$ and $(R) /(S)-9(\mathrm{Bn}=$ benzyl).

In all successful cases, a practically exclusive attack of the enolate $R e$ face on the aldehyde carbonyl $R e$ face was 5 observed. ${ }^{10}$ We explained the stereochemical course of these aldol reactions by assuming the generally accepted model of cyclic, six-membered transition states of the ZimmermanTraxler type (Scheme 1). ${ }^{11,12}$ In the case of $\alpha$-chiral aldehydes, where issues of double diastereoselection are at 10 work, ${ }^{\text {a-c }}$ we completed the mechanistic paradigm with the inclusion of the Felkin-Anh model and its subsequent refinements. ${ }^{13,14}$ As matters evolved, however, we found that strict adherence to this model did not allow for a satisfactory account of all observed results, most particularly with

15 aldehydes having highly electronegative atoms $(\mathrm{F}, \mathrm{O})$ bound to the $\alpha$-carbon. In such cases, it was found that additional inclusion of features of the Cornforth model $^{15}$ provided a much better explanation. ${ }^{8,9}$ This conclusion was further supported by means of density funcional calculations. ${ }^{9}$

20 Short after the beginning of our research on boron aldol reactions with ketone $\mathbf{1}$, and relying on findings of Paterson and coworkers, ${ }^{6 a}$ we wondered whether the replacement of one or more of the electron-donating $O$-protecting groups of 1 by electron-withdrawing counterparts would change from syn

25 to anti the stereochemical course of the aldol reaction. Indeed, and in line with Paterson's idea, chiral ketone 13, which bears two benzoyl protecting groups, was found to stereoselectively give anti aldols 14 with achiral aldehydes (Scheme 3$),{ }^{16}$ most likely through the corresponding $E$ boron enolate. ${ }^{17}$ Later 30 quantum-mechanical studies of our group provided theoretical basis for this mechanistic assumption. ${ }^{5 \mathrm{~d}}$ In a more recent development, the dibenzoylated ketone $\mathbf{1 3}$ has been replaced by its monobenzoylated counterpart $\mathbf{1 5}$, which is easier to prepare and yields anti aldols 16 with similar degrees of ${ }^{35}$ stereoselectivity. ${ }^{18}$

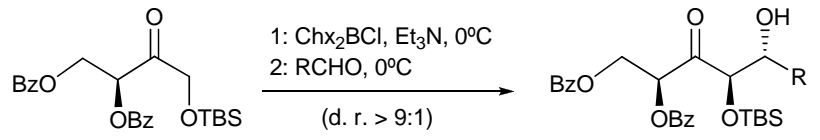

13

$$
14
$$<smiles>[R16]CC(C)CCC(C)CC</smiles>

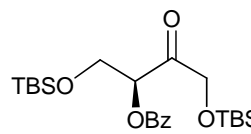

15

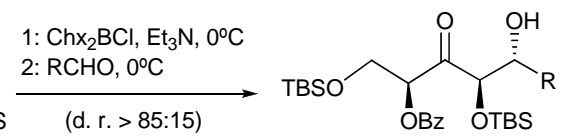

16
Scheme 3 Anti aldol additions of boron enolates of ketones $\mathbf{1 3}$ and $\mathbf{1 5}$ to achiral aldehydes $(\mathrm{Bz}=$ benzoyl).

The purpose of the present investigation is the study of the 40 double diastereoselection in anti aldol reactions of ketone $\mathbf{1 5}$ with $\alpha$-chiral aldehydes.

\section{Results and discussion}

The $\alpha$-chiral aldehydes $(R) /(S)-3,(R) /(S)-4$ and $(R) /(S)-9$, used in the present study (Fig. 1), are also those of our previous ${ }_{45}$ publications $^{8,9}$ and have been prepared by means of the same procedures ( $\alpha$-fluoro aldehydes 8 have not been included in the present study).
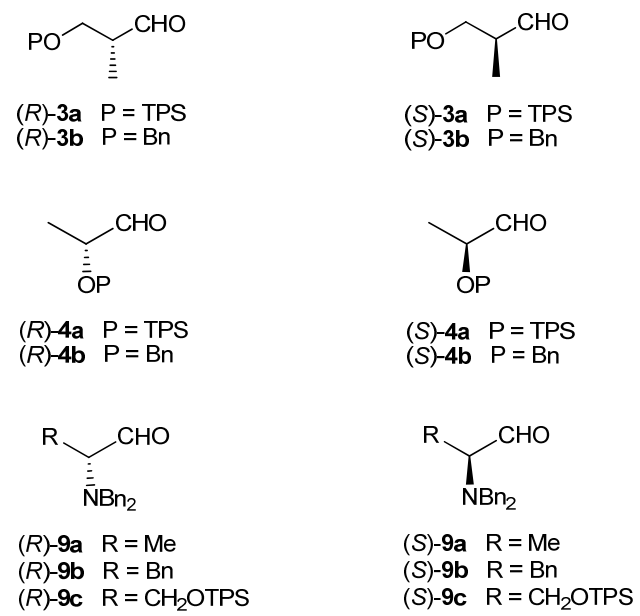

Fig. $1 \alpha$-Chiral aldehydes used in this study (TPS = tert${ }_{50}$ butyldiphenylsilyl)

The results of the aldol reactions are presented in Scheme 4. Ketone $\mathbf{1 5}$ is assumed to be first converted into $E$ enolate $15_{\mathbf{B}}$. The latter then reacts with the aldehydes to yield the anti aldols 17-20, obtained as essentially single diastereoisomers 55 in the majority of cases. Exceptions to this behaviour were aldehydes (R)-3a,b and (S)-4a,b, which gave complex mixtures, accompanied by ill-defined decomposition products. Furthermore, aldol 19a was obtained as an 88:12 mixture (for the methods used to establish the stereostructures of these 60 aldols, see the Supporting Information). 


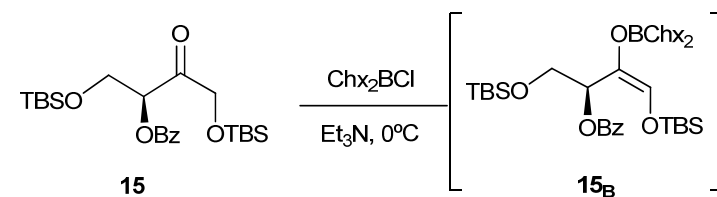

$15_{\mathrm{B}} \stackrel{(R)-3 \mathrm{a}, \mathrm{b}}{\longrightarrow}$ Complex mixtures (+ decomp.)

$15_{B} \underset{\text { d.r.>95:5 }}{\stackrel{(S)-3 a, b}{\longrightarrow}}$ TBSO $\overbrace{O B z}$

$15_{\mathrm{B}} \underset{\text { d.r. }>95: 5}{\stackrel{(R)-4 \mathbf{a}, \mathbf{b}}{\longrightarrow}}$ TBSO $\overbrace{\mathrm{OBz}}$

$15_{\mathrm{B}} \stackrel{(S)-\mathbf{4 a , b}}{\longrightarrow}$ Complex mixtures $(+$ decomp.)

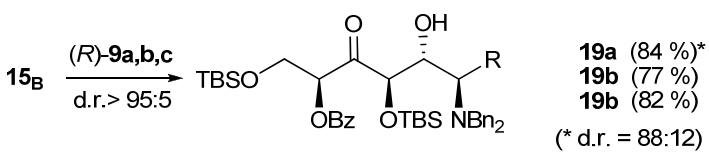

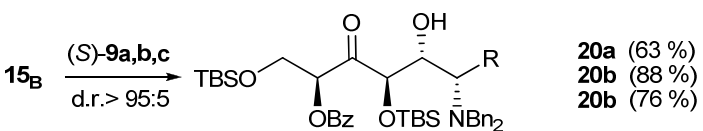

Scheme 4 Aldol additions of an $E$ enolate of ketone $\mathbf{1 5}$ to aldehydes $(R) /(S)$-3a,b, $(R) /(S)-\mathbf{4 a}, \mathbf{b}$ and $(R) /(S)-9 \mathbf{a}, \mathbf{b}, \mathbf{c}$. D.r. $>$ 95:5 unless otherwise stated (for the meaning of $P$ and $R$, see ${ }_{5}$ Fig. 1).

For a mechanistic explanation of the stereochemical course of these reactions, we cannot directly adapt the chair-like Zimmerman-Traxler model used in our previous publications that discussed the formation of syn aldols via $Z$ enolates. ${ }^{8,9}$
10 Indeed, theoretical calculations of our group have led to the proposal that anti aldol reactions of ketone $\mathbf{1 3}$ with achiral aldehydes mediated by $\mathrm{Chx}_{2} \mathrm{BCl}$ take place through a transition structure (TS) of the "boat B" type (Scheme 5). ${ }^{5 \mathrm{~d}, 12 \mathrm{~g}}$ One salient feature of this TS is the arrangement of the groups 15 around the stereocentre in the enolate moiety, which is in such a way as to minimize the 1,3 -allylic strain ${ }^{19}$ within the enolate $E$ olefinic bond. As a consequence, the benzoate points inside the cyclic TS but, due to the boat shape of the latter, this does not lead here to a steric crowding with the cyclohexyl ligands 20 at the boron atom (compare with the chair-like TS in Scheme $1)$.

If we wish to extend this mechanistic view to the aldol reactions of ketone $\mathbf{1 5}$ with $\alpha$-chiral aldehydes (Scheme 4), it is also necessary to add to the general model all the other 25 factors which were taken into account in our previous papers $^{8,9}$ on aldol reactions of ketone 1, i.e. the Felkin-Anh and Cornforth paradigms. ${ }^{13-15}$

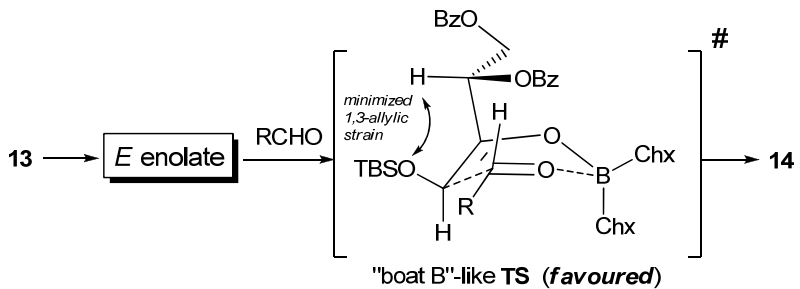

Scheme 5 Proposed TS for the aldol addition step of the $E$ 30 boron enolate of ketone $\mathbf{1 3}$ and achiral aldehydes RCHO.

The case of $\alpha$-methyl aldehydes $(R)$ - and (S)-3a,b will be studied fist. According to Scheme 4, aldehydes (S)-3a,b reacted with enolate $15_{\mathbf{B}}$ to yield anti aldols 17a,b with good yields and excellent diastereoselectivity. In contrast, the same 35 reaction with aldehydes $(R)-\mathbf{3 a}, \mathbf{b}$ only gave aldol mixtures, accompanied by decomposition products.

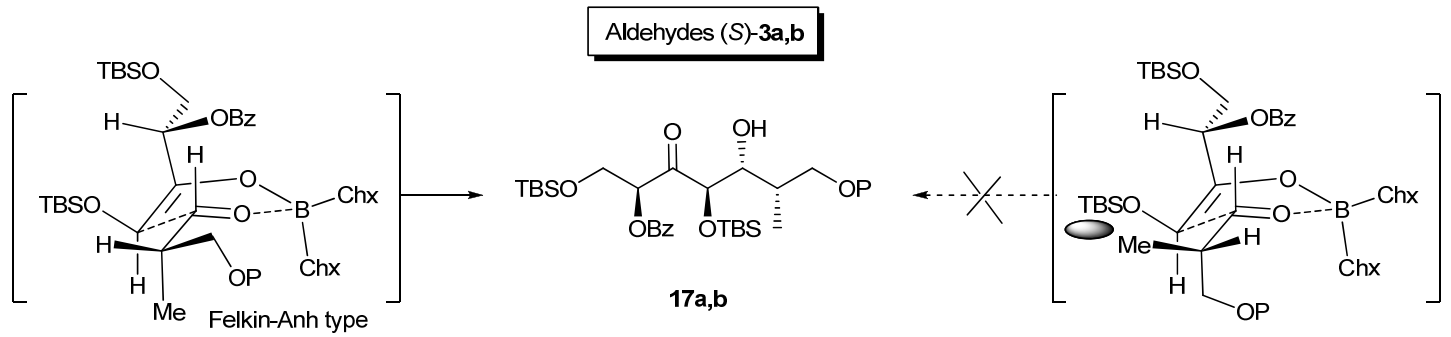

TS-1 (favourable, no syn pentane effects)

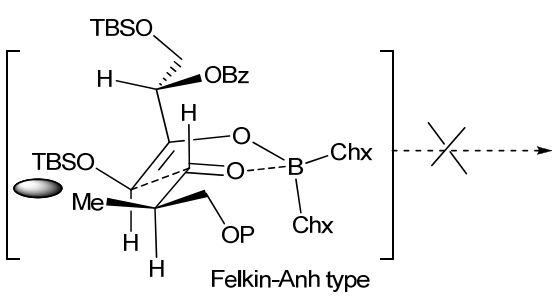

TS-3 (unfavourable, syn pentane)
Aldehydes (R)-3a,b

aldol mixture (+ decomp. products)
TS-2 (unfavourable, non-Anh and syn pentane)

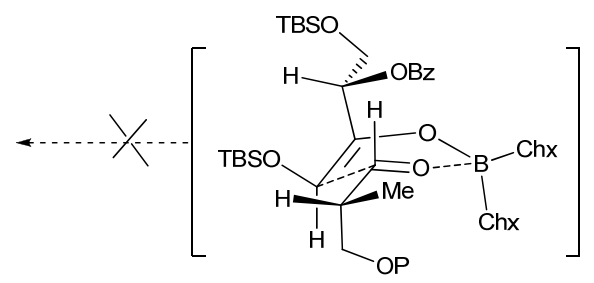

TS-4 (unfavourable, non-Anh) 
Scheme 6 Proposed TSs for the aldol addition step of boron enolate $\mathbf{1 5}_{\mathbf{B}}$ to $\alpha$-methyl aldehydes $(R)$ - and $(S)$-3a,b.

If the stereochemical model of Scheme 5 is applied to the reactions of $15_{\mathbf{B}}$ with aldehydes $(R)$ - and $(S)$-3a,b, we obtain 5 the four boat-like transition structures (TS-1 to TS-4) depicted in Scheme 6. The formation of aldols 17a,b in the case of (S)-3a,b can be reasonably explained with transition structure TS-1. It can be seen that the spatial arrangement of the three groups at the $\alpha$-carbon of the aldehyde $(\mathrm{H}, \mathrm{Me}$,

${ }_{10} \mathrm{CH}_{2} \mathrm{OP}$ ) closely adheres to the Felkin-Anh model (anti orientation of the bulky $\mathrm{CH}_{2} \mathrm{OP}$ group and the attacking nucleophile). Since no unfavourable steric features are present in TS-1, it is not surprising that these reactions take place with good results, both in terms of yield and stereoselectivity, 15 to yield yield anti aldols 17a,b. Rotation of the aldehyde $\mathrm{C}_{\alpha}-\mathrm{CO}$ bond in TS-1 yields the alternative transition structure TS-2, which would yield in principle the same final product. However, this is markedly higher in energy contents, as it shows two very unfavourable features: a) a non-Anh 20 arrangement ${ }^{20}$ of the three groups at the $\alpha$-carbon of the aldehyde. b) a syn pentane interaction ${ }^{21,22}$ between the Me and OTBS groups. Particularly the latter effect has been shown to be quantitatively very important in aldol and allylation reactions, often overriding the stereoelectronic preference 25 associated to a Felkin-Anh geometry. ${ }^{8,9,21}$ In consequence, we may assume than the aldol reactions of $\mathbf{1 5}_{\mathbf{B}}$ with aldehydes (S)-3a,b take place only through TS-1.

The situation is different in the case of aldehydes $(R)$-3a,b, which react with $\mathbf{1 5}_{\mathbf{B}}$ to give complex mixtures of aldols 30 together with decomposition products (Scheme 4). In Scheme 6 , a plausible explanation for this result is proposed. The reaction may take place through either TS-3 or TS-4: TS-3 is of the Felkin-Anh type but also shows an unfavourable syn pentane interaction, whereas TS-4 is of the non-Anh type. ${ }_{35}$ Both reactions therefore must traverse unfavourable transition structures and become accordingly slower, with the expected loss of stereoselectivity and increased probability of decomposition pathways.

A similar situation is found in the case of $\alpha$-oxygenated 40 aldehydes $(R)$ - and (S)-4a,b, even though the $R$ enantiomers are those reacting efficiently here, with the $S$ enantiomers giving complex aldol mixtures and decomposition products (Scheme 4). As above, four boat-like transition structures (TS-5 to TS-8), depicted in Scheme 7, may be proposed for 45 these reactions. In the same line of reasoning disclosed above, the successful reactions of aldehydes $(R)-\mathbf{4 a}$, b are proposed to occur through transition structures like TS-6, which is of the Felkin-Anh type and does not display unfavourable steric features. In contrast, TS-5 shows an unfavourable syn pentane 50 effect. The same effects are also seen in transition structures TS-7 and TS-8, which should be relevant for the reactions of aldehydes (S)-4a,b. It is thus not surprising that these reactions yield complex aldol mixtures and decomposition products. It is also worth mentioning that TS-8 also belongs to 55 the Felkin-Anh type ${ }^{13}$ (see above) whereas TS-5 and TS-7 belong to the Cornforth type (anti orientation of the electronegative OP group and the aldehyde $\mathrm{C}=\mathrm{O}$ bond). ${ }^{15}$ Nonetheless, the energetically important contribution of the syn pentane interaction is able to override the aforementioned 60 effects.

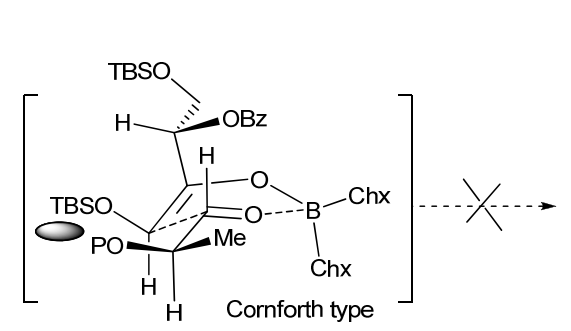

TS-5 (unfavourable, syn pentane)

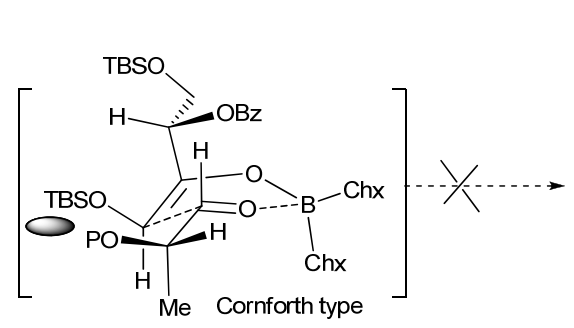

TS-7 (unfavourable, syn pentane)

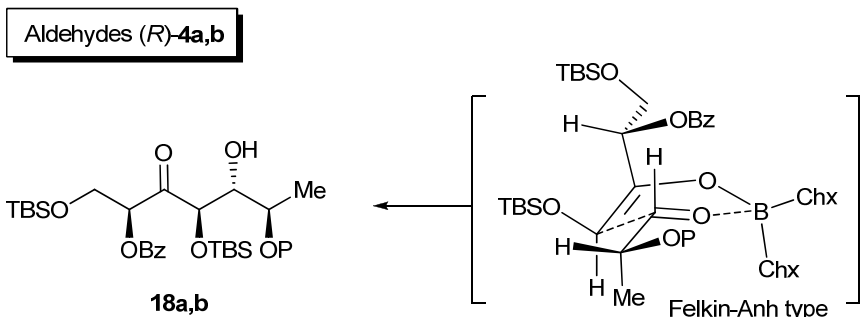

TS-6 (favourable, no syn pentane effects)

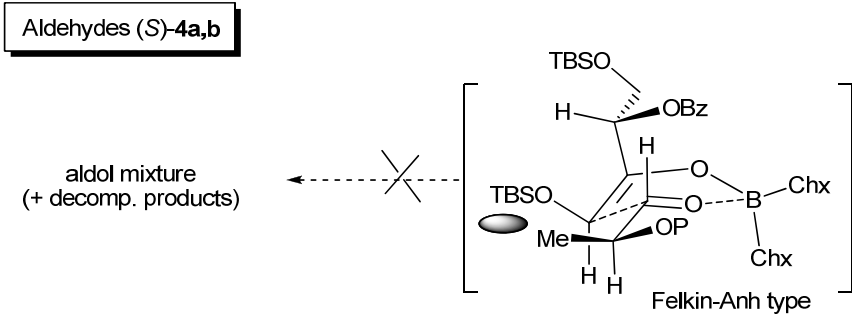

TS-8 (unfavourable, syn pentane)

Scheme 7 Proposed TSs for the aldol addition step of boron enolate $\mathbf{1 5}_{\mathbf{B}}$ to $\alpha$-oxygenated aldehydes $(R)$ - and $(S)-\mathbf{4 a , b}$.

${ }_{65}$ The aldol reactions of the $\alpha$-amino aldehydes $\mathbf{9 a , b , c}$ showed a difference with the previous cases. Indeed, both $(R)-$ and $(S)-9 \mathbf{a}, \mathbf{b}, \mathbf{c}$ did react with enolate $\mathbf{1 5}_{\mathbf{B}}$ and yielded aldol adducts (19 and 20, respectively) with good yields and, in 
most cases, high diastereoselectivity. An application of the previous models to the reactions of these aldehydes would yield the transition structures TS-9 to TS-12, all of them depicted in Scheme 8. The aldol reactions of aldehydes $(R)$ s 9a,b,c to yield 19a,b,c can be thought to occur via transition structure TS-10, which is of the Felkin-Anh type and does not display unfavourable steric features. The alternative, Cornforth-type TS-9 shows a syn pentane effect and can thus be ruled out.

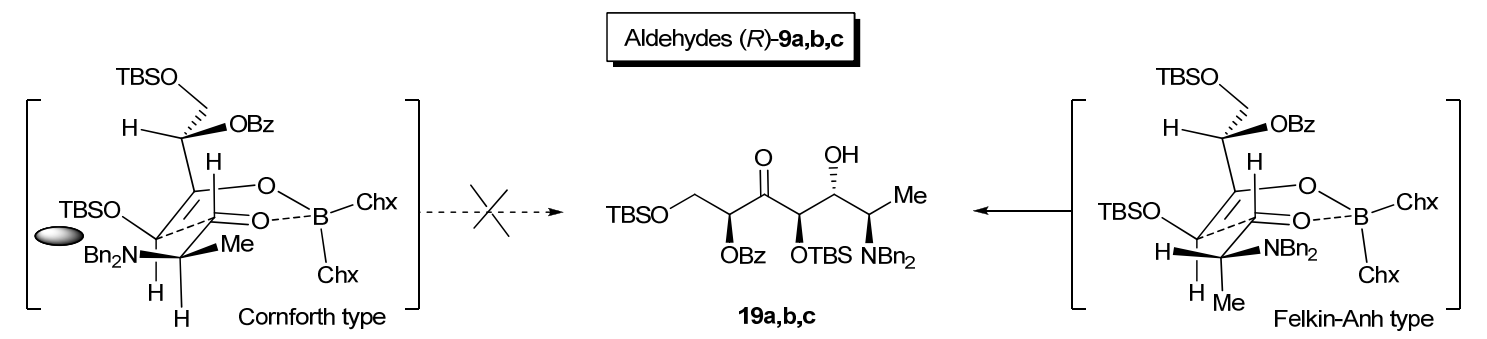

TS-9 (unfavourable, syn pentane)

TS-10 (favourable, no syn pentane effects)

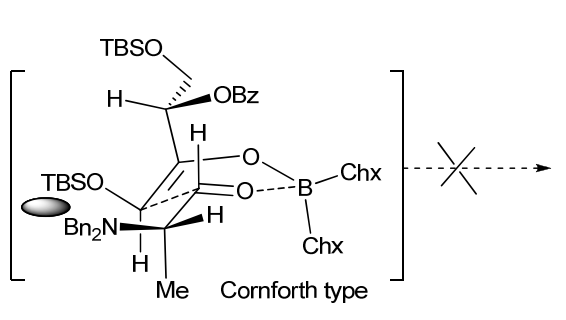

Aldehydes (S)-9a,b,c

TS-11 (unfavourable, syn pentane)

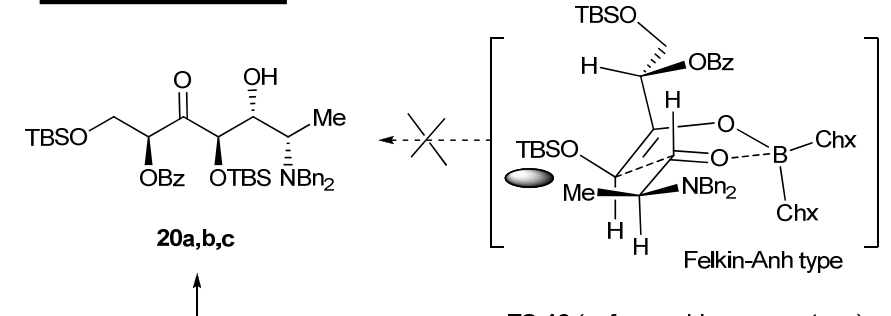

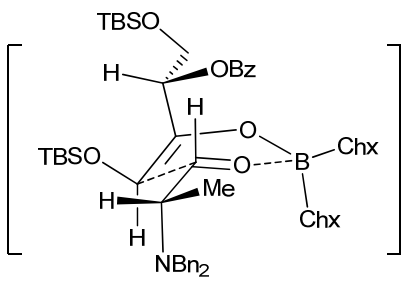

TS-12 (unfavourable, syn pentane)

TS-13 (no syn pentane interactions)

Scheme 8 Proposed TSs for the aldol addition step of boron enolate $\mathbf{1 5}_{\mathbf{B}}$ to $\alpha$-amino aldehydes $(R)$ - and (S)-9a,b,c.

As regards the aldol reactions of aldehydes (S)-9a,b,c, TS1511 (Cornforth) and TS-12 (Felkin-Anh) would seem in principle suitable TSs. However, both show a syn pentane interaction. Accordingly, and as observed for aldehydes (S)4a,b, only complex aldol mixtures and decomposition products should be expected. Instead, aldols $\mathbf{2 0 a , b , c}$ are 20 diastereoselectively formed with good yields.

A plausible explanation for this result is the assumption of the alternative TS-13, which is devoid of energetically unfavourable syn pentane effects, even if it shows neither the stereoelectronic benefit of the Felkin-Anh geometry nor the ${ }_{25}$ favourable Cornforth-like anti arrangement of the polar $\mathrm{C}=\mathrm{O}$ and $\mathrm{C}-\mathrm{N}$ bonds. As commented above, syn pentane effects have been shown to be quantitatively very important in aldol and allylation reactions, often overriding the stereoelectronic preference associated to a Felkin-Anh geometry. ${ }^{8,9,21}$ 30 Moreover, the lower electronegativity of nitrogen as compared with oxygen may make the energetic advantage of the Cornforth geometry in the former case less important than in the latter. Indeed, as previously observed in the aldol additions of the $Z$ enolate $\mathbf{1}_{\mathbf{B}}$, Cornforth-like TSs are relevant
35 mainly for aldehydes bearing highly electronegative atoms $(\mathrm{O}, \mathrm{F})$ in the $\alpha$ carbon but even in this case, the minimization of the dipolar repulsion was not found able to override a syn pentane effect. ${ }^{9}$

\section{Experimental}

\section{${ }_{40}$ General}

NMR spectra were recorded at $500 \mathrm{MHz}\left({ }^{1} \mathrm{H} \mathrm{NMR}\right)$ and 125 $\mathrm{MHz}\left({ }^{13} \mathrm{C} \mathrm{NMR}\right)$ in $\mathrm{CDCl}_{3}$ solution at $25{ }^{\circ} \mathrm{C}$, if not otherwise indicated, with the solvent signals as internal reference. ${ }^{13} \mathrm{C}$ NMR signal multiplicities were determined with the DEPT pulse 45 sequence. Mass spectra were run in the EI $(70 \mathrm{eV})$, the FAB ( $m$ nitrobenzyl alcohol matrix) or the electrospray (ESMS) mode. IR data, which were measured as films on $\mathrm{NaCl}$ plates (oils) or as $\mathrm{KBr}$ pellets (solids), are given only when relevant functions $(\mathrm{C}=\mathrm{O}, \mathrm{OH})$ are present. Optical rotations were measured at $25^{\circ} \mathrm{C}$. ${ }_{50}$ Reactions which required an inert atmosphere (all except those involving water in the reaction medium) were carried out under dry $\mathrm{N}_{2}$ with flame-dried glassware. Commercial reagents were used as received. THF and $\mathrm{Et}_{2} \mathrm{O}$ were freshly distilled from 
sodium-benzophenone ketyl. Dichloromethane was freshly distilled from $\mathrm{CaH}_{2}$. Toluene was freshly distilled from sodium wire. Tertiary amines were freshly distilled from $\mathrm{KOH}$. Unless detailed otherwise, "work-up" means pouring the reaction 5 mixture into brine, followed by extraction with the solvent indicated in parenthesis. If the reaction medium was acidic, an additional washing of the organic layer with $5 \%$ aq $\mathrm{NaHCO}_{3}$ was performed. If the reaction medium was basic, an additional washing with aq $\mathrm{NH}_{4} \mathrm{Cl}$ was performed. Where solutions were

10 filtered through a Celite pad, the pad was additionally washed with the same solvent used, and the washings incorporated to the main organic layer. The latter was dried over anhydrous $\mathrm{Na}_{2} \mathrm{SO}_{4}$ and the solvent was eliminated under reduced pressure. Column chromatography of the residue on a silica gel column (60-200

$15 \mu \mathrm{m})$ was performed with elution with the indicated solvent mixture.

General experimental procedure for aldol additions of ketone 15 mediated by dicyclohexylboron chloride. $\mathrm{Chx}_{2} \mathrm{BCl}$ (neat, $395 \mu \mathrm{L}$, ca. $1.8 \mathrm{mmol}$ ) was added under $\mathrm{Ar}$ via syringe to an ice20 cooled solution of $\mathrm{Et}_{3} \mathrm{~N}(280 \mu \mathrm{L}, 2 \mathrm{mmol})$ in anhydrous $\mathrm{Et}_{2} \mathrm{O}(5$ $\mathrm{mL})$. Erythrulose derivative 15 (453 mg, $1 \mathrm{mmol})$ was dissolved in anhydrous $\mathrm{Et}_{2} \mathrm{O}(5 \mathrm{~mL})$ and added dropwise via syringe to the reagent solution. The reaction mixture was then stirred for 30 min. and then cooled to $-78^{\circ} \mathrm{C}$. After dropwise addition of a 25 solution of the appropriate aldehyde ${ }^{8,9}(4 \mathrm{mmol})$ in anhydrous ether $(6 \mathrm{~mL})$, the reaction mixture was stirred at $-78^{\circ} \mathrm{C}$ for $5 \mathrm{~h}$.

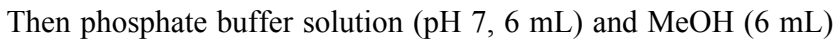
were added, followed by $30 \%$ aq $\mathrm{H}_{2} \mathrm{O}_{2}$ solution $(3 \mathrm{~mL})$. After stirring for $1 \mathrm{~h}$ at room temperature, the mixture was worked up

30 (extraction with $\mathrm{Et}_{2} \mathrm{O}$ ). Removal of volatiles under reduced pressure and column chromatography of the residue on silica gel (hexanes-EtOAc mixtures) afforded the aldol addition product. Yields and diastereoisomeric ratios are indicated in Scheme 4.

(2S,4R,5R,6S)-2-(Benzoyloxy)-1,4-bis-(tert-

${ }_{35}$ butyldimethylsilyloxy)-7-(tert-butyldiphenylsilyloxy)-5-

hydroxy-6-methylheptan-3-one (17a). Oil: $[\alpha]_{\mathrm{D}}+2.2$ (c 1.1; $\mathrm{CHCl}_{3}$ ); IR $v_{\max } 3490$ (br, OH), $1728(\mathrm{br}, \mathrm{C}=\mathrm{O})\left(\mathrm{cm}^{-1}\right) ;{ }^{1} \mathrm{H}$ NMR $\delta 8.10(2 \mathrm{H}$, br d, $J \sim 7.5 \mathrm{~Hz}$; aromatic), 7.70-7.65 (4H, m; aromatic), $7.57(1 \mathrm{H}$, br t, $J \sim 7.5 \mathrm{~Hz}$; aromatic), 7.45-7.35 $(8 \mathrm{H}$, br $40 \mathrm{~m}$; aromatic), $5.81(1 \mathrm{H}, \mathrm{dd}, J=6.3,3.3 \mathrm{~Hz} ; \mathrm{H}-2), 4.47(1 \mathrm{H}, \mathrm{d}, J=$ $8 \mathrm{~Hz}$; H-4), 4.25-4.20 (2H, m; H-1/H-5), $4.12(1 \mathrm{H}, \mathrm{dd}, J=11.2$, $6.3 \mathrm{~Hz}$; H-1'), 3.76 (1H, dd, $J=10,4.3 \mathrm{~Hz}$; H-7), 3.70 (1H, dd, $J$ $=10,5.5 \mathrm{~Hz}$; H-7'), $3.30(1 \mathrm{H}$, br s; $\mathrm{OH}), 2.05(1 \mathrm{H}, \mathrm{br} \mathrm{m} ; \mathrm{H}-6)$, 1.06 (9H, s; $\mathrm{Me}_{3} \mathrm{CSi}$ ), 0.96 (3H, d, $\left.J=7 \mathrm{~Hz} ; \mathrm{Me}-\mathrm{C} 6\right), 0.92$ (9H, s; ${ }_{45} \mathrm{Me}_{3} \mathrm{CSi}$ ), 0.88 (9H, s; $\left.\mathrm{Me}_{3} \mathrm{CSi}\right), 0.10$ (3H, s; $\left.\mathrm{MeSi}\right), 0.09$ (3H, s; $\mathrm{MeSi}$ ), 0.08 (3H, s; MeSi), 0.07 (3H, s; MeSi); ${ }^{13} \mathrm{C}$ NMR $\delta 206.5$, 166.1, 133.3, 133.2, 129.4, 19.2, 18.3, 18.1 (quat C), 135.6 (x 2), 135.5 (x 2), 133.2 (x 2), 129.9 (x 2), 129.7 (x 2), 128.4 (x 2), 127.7 (x 3), 78.2, 77.6, 75.0, 35.7 (CH), 68.3, $62.4\left(\mathrm{CH}_{2}\right), 26.9(\mathrm{x}$ ${ }_{50} 3, \mathrm{Me}_{3} \mathrm{CSi}$ ), 25.8 (x 6, $2 \mathrm{Me}_{3} \mathrm{CSi}$ ), 9.6 (Me-C6), -4.4 (MeSi), -5.0 (MeSi), -5.4 (x 2, $2 \mathrm{MeSi}$ ); HR EIMS m/z (\% rel. int.) 721.3425 $\left(\mathrm{M}^{+}-t \mathrm{Bu}, 2\right), 269$ (22), 105 (100), calcd. for $\mathrm{C}_{43} \mathrm{H}_{66} \mathrm{O}_{7} \mathrm{Si}_{3}-t \mathrm{Bu}$, 721.3412 .

(2S,4R,5R,6S)-2-(Benzoyloxy)-7-(benzyloxy)-1,4-bis-(tert${ }_{55}$ butyldimethylsilyloxy)-5-hydroxy-6-methylheptan-3-one (17b). Oil: $[\alpha]_{\mathrm{D}}-2.2$ (c 1.4; $\mathrm{CHCl}_{3}$ ); IR $v_{\max }\left(\mathrm{cm}^{-1}\right): 3490$ (br, $\mathrm{OH}), 1726$ (br, C=O); ${ }^{1} \mathrm{H}$ NMR $(500 \mathrm{MHz}) \delta 8.10$ (2H, br d, $J \sim$
$7.5 \mathrm{~Hz}$; aromatic), 7.57 (1H, br t, $J \sim 7.5 \mathrm{~Hz}$; aromatic), $7.41(2 \mathrm{H}$, br t, $J \sim 7.5 \mathrm{~Hz}$; aromatic), 7.40-7.25 (5H, br m; aromatic), 5.79 60 (1H, br t, $J \sim 4.3 \mathrm{~Hz}$; H-2), 4.50-4.45 (3H, m; H-4/benzyl), 4.154.10 (3H, m; H-1/H-1'/H-5), 3.55-3.50 (2H, m; H-7/H-7'), 3.20 $(1 \mathrm{H}, \mathrm{d}, J=5 \mathrm{~Hz} ; \mathrm{OH}), 2.08(1 \mathrm{H}, \mathrm{br} \mathrm{m} ; \mathrm{H}-6), 0.97$ (3H, d, $J=7$ $\mathrm{Hz}$; Me-C6), 0.88 (9H, s; $\left.\mathrm{Me}_{3} \mathrm{CSi}\right), 0.86$ (9H, s; $\left.\mathrm{Me}_{3} \mathrm{CSi}\right), 0.08$ (6H, s; $2 \mathrm{MeSi}$ ), 0.06 (3H, s; MeSi), 0.05 (3H, s; MeSi); ${ }^{13} \mathrm{C}$ NMR ${ }_{65}(125 \mathrm{MHz}) \delta 206.6,166.0,138.3,129.5,18.3,18.1$ (quat $\mathrm{C}$ ), 133.3 (x 2), 130.0 (x 2), 128.4 (x 3), 127.6 (x 3), 78.6, 78.1, 74.6, $34.3(\mathrm{CH}), 74.3,73.2,62.7\left(\mathrm{CH}_{2}\right), 25.8$ (x 6, $\left.2 \mathrm{Me}_{3} \mathrm{CSi}\right), 10.5$ (Me-C6), -4.4 (MeSi), -5.0 (MeSi), -5.4 (x 2, $2 \mathrm{MeSi})$; HR FABMS $m / z \quad 631.3476\left(\mathrm{M}+\mathrm{H}^{+}\right)$. Calcd. for $\mathrm{C}_{34} \mathrm{H}_{55} \mathrm{O}_{7} \mathrm{Si}_{2}$, 70631.3486.

\section{$(2 S, 4 R, 5 R, 6 R)-2-(B e n z o y l o x y)-1,4-b i s-(t e r t-$}

butyldimethylsilyloxy)-6-(tert-butyldiphenylsilyloxy)-5-

hydroxyheptan-3-one (18a). Oil: $[\alpha]_{\mathrm{D}}-2$ (c 2.2; $\left.\mathrm{CHCl}_{3}\right)$; IR $v_{\max }\left(\mathrm{cm}^{-1}\right): 3470(\mathrm{br}, \mathrm{OH}), 1729(\mathrm{br}, \mathrm{C}=\mathrm{O}) ;{ }^{1} \mathrm{H} \mathrm{NMR}(500 \mathrm{MHz})$ $75 \delta 8.11(2 \mathrm{H}$, br d, $J \sim 7.5 \mathrm{~Hz}$; aromatic), $7.72(2 \mathrm{H}$, br t, $J \sim 7 \mathrm{~Hz}$; aromatic), $7.60(1 \mathrm{H}$, br t, $J \sim 7.5 \mathrm{~Hz}$; aromatic), 7.50-7.25 $(10 \mathrm{H}$, br m; aromatic), $5.85(1 \mathrm{H}$, br t, $J \sim 4.5 \mathrm{~Hz} ; \mathrm{H}-2), 4.70(1 \mathrm{H}, \mathrm{d}, J=$ $7 \mathrm{~Hz}$; H-4), 4.20-4.15 (2H, m; H-1/H-1'), 4.10 (1H, br quint, $J$ $5.5 \mathrm{~Hz}$; H-6), 3.90 (1H, br t, $J \sim 5.5 \mathrm{~Hz}$; H-5), 2.90 (1H, br s; $\left.{ }_{80} \mathrm{OH}\right), 1.08\left(9 \mathrm{H}, \mathrm{s} ; \mathrm{Me}_{3} \mathrm{CSi}\right), 1.05(3 \mathrm{H}, \mathrm{d}, J=6.5 \mathrm{~Hz} ; \mathrm{H}-7), 0.92$ (9H, s; $\left.\mathrm{Me}_{3} \mathrm{CSi}\right), 0.86$ (9H, s; $\left.\mathrm{Me}_{3} \mathrm{CSi}\right), 0.13$ (3H, s; MeSi), 0.10 $(6 \mathrm{H}, \mathrm{s} ; 2 \times \mathrm{MeSi}), 0.07(3 \mathrm{H}, \mathrm{s} ; \mathrm{MeSi}) ;{ }^{13} \mathrm{C} \mathrm{NMR}(125 \mathrm{MHz}) \delta$ 205.8, 165.9, 134.2, 133.2, 129.6, 19.2, 18.3, 18.0 (quat C), 135.7 (x 4), 129.9 (x 2), 129.7, 129.5 (x 2), 128.4 (x 2), 127.6 (x 2), ${ }_{85} 127.5$ (x 2), 79.0, 78.0, 76.6, $69.7(\mathrm{CH}), 62.2\left(\mathrm{CH}_{2}\right), 26.9$ (x 3, $\mathrm{Me}_{3} \mathrm{CSi}$ ), 25.8 (x 6, $2 \mathrm{Me}_{3} \mathrm{CSi}$ ), 16.9 (C7), -4.4 (MeSi), -5.0 (MeSi), -5.4 (x 2, $2 \mathrm{MeSi}$ ); HR EIMS m/z (\% rel. int.) 707.3249 $\left(\mathrm{M}^{+}-t \mathrm{Bu}, 1\right), 255$ (90), 105 (100). Calcd. for $\mathrm{C}_{42} \mathrm{H}_{64} \mathrm{O}_{7} \mathrm{Si}_{3}-t \mathrm{Bu}$, 707.3255 .

\section{0 (2S,4R,5R,6R)-2-(Benzoyloxy)-6-(benzyloxy)-1,4-bis-(tert-} butyldimethylsilyloxy)-5-hydroxyheptan-3-one (18b). Oil: $[\alpha]_{D}$ -11.2 (c 1.15; $\mathrm{CHCl}_{3}$ ); IR $v_{\max }\left(\mathrm{cm}^{-1}\right): 3470$ (br, $\left.\mathrm{OH}\right), 1727$ (br, $\mathrm{C}=\mathrm{O}) ;{ }^{1} \mathrm{H}$ NMR $(500 \mathrm{MHz}) \delta 8.10(2 \mathrm{H}$, br $\mathrm{d}, J \sim 7.5 \mathrm{~Hz}$; aromatic), $7.60(1 \mathrm{H}$, br t, $J \sim 7.5 \mathrm{~Hz}$; aromatic), $7.48(2 \mathrm{H}, \mathrm{br} \mathrm{t}, J \sim$ ${ }_{95} 7.5 \mathrm{~Hz}$; aromatic), 7.35-7.25 (5H, br m; aromatic), $5.65(1 \mathrm{H}, \mathrm{dd}, J$ $=5.5,3 \mathrm{~Hz} ; \mathrm{H}-2), 4.75(1 \mathrm{H}, \mathrm{d}, J=4.4 \mathrm{~Hz} ; \mathrm{H}-4), 4.46(1 \mathrm{H}, \mathrm{d}, J=$ $11.7 \mathrm{~Hz}$; benzyl), $4.32(1 \mathrm{H}, \mathrm{d}, J=11.7 \mathrm{~Hz}$; benzyl), $4.04(1 \mathrm{H}, \mathrm{dd}$, $J=11.3,5.5 \mathrm{~Hz}$; H-1), 3.96 (1H, dd, $\left.J=11.3,3 \mathrm{~Hz} ; \mathrm{H}-1^{\prime}\right), 3.91$ $(1 \mathrm{H}$, br td, $J \sim 8.5,4.4 \mathrm{~Hz}$; H-5), $3.56(1 \mathrm{H}, \mathrm{br} \mathrm{dq}, J=8.5,6.5 \mathrm{~Hz}$; $100 \mathrm{H}-6), 2.60$ (1H, d, $J=9 \mathrm{~Hz} ; \mathrm{OH}), 1.24(3 \mathrm{H}, \mathrm{d}, J=6.5 \mathrm{~Hz} ; \mathrm{H}-7)$, 0.98 (9H, s; $\left.\mathrm{Me}_{3} \mathrm{CSi}\right), 0.85$ (9H, s; $\left.\mathrm{Me}_{3} \mathrm{CSi}\right), 0.18$ (3H, s; MeSi), $0.12(3 \mathrm{H}, \mathrm{s} ; \mathrm{MeSi}), 0.03(3 \mathrm{H}, \mathrm{s} ; \mathrm{MeSi}), 0.00(3 \mathrm{H}, \mathrm{s} ; \mathrm{MeSi}) ;{ }^{13} \mathrm{C}$ NMR $(125 \mathrm{MHz}) \delta 203.2,165.8,138.2,129.5,19.2,18.3,18.2$ (quat C), 133.3, 129.8 (x 2), 128.5 (x 2), 128.2 (x 2), 128.0 (x 2), 105 127.5, 78.8, 78.4, 76.2, 70.6 (CH), 74.0, $62.3\left(\mathrm{CH}_{2}\right), 25.9$ (x 3, $\mathrm{Me}_{3} \mathrm{CSi}$ ), 25.7 (x 3, Me $3 \mathrm{CSi}$ ), 15.9 (C7), -4.4 (MeSi), -5.1 (MeSi), -5.4 (x 2, $2 \mathrm{MeSi})$; HR FABMS $m / z 617.3353\left(\mathrm{M}+\mathrm{H}^{+}\right)$. Calcd. for $\mathrm{C}_{33} \mathrm{H}_{53} \mathrm{O}_{7} \mathrm{Si}_{2}, 617.3329$.

(2S,4R,5R,6R)-2-(Benzoyloxy)-1,4-bis-(tert110 butyldimethylsilyloxy)-6-( $N, N$-dibenzylamino)-5-

hydroxyheptan-3-one (19a). Obtained as an 88:12 mixture with a diastereoisomer. Chromatographic separation gave the major diastereoisomer 20a: oil: $[\alpha]_{\mathrm{D}}+11.5\left(\right.$ c $\left.1.18 ; \mathrm{CHCl}_{3}\right)$; IR $v_{\max }$ $\left(\mathrm{cm}^{-1}\right): 3460$ (br, OH), 1726 (br, $\left.\mathrm{C}=\mathrm{O}\right) ;{ }^{1} \mathrm{H}$ NMR $(500 \mathrm{MHz}) \delta$ 
8.19 (2H, br d, $J \sim 8 \mathrm{~Hz}$; aromatic), $7.66(1 \mathrm{H}$, br t, $J \sim 7.5 \mathrm{~Hz}$; aromatic), $7.54(2 \mathrm{H}$, br t, $J \sim 7.5 \mathrm{~Hz}$; aromatic), 7.35-7.15 $(10 \mathrm{H}$, br m; aromatic), 5.77 (1H, br t, $J \sim 4 \mathrm{~Hz}$; H-2), 4.44 (1H, m; H-5), $4.30(1 \mathrm{H}, \mathrm{d}, J=7.3 \mathrm{~Hz} ; \mathrm{H}-4), 4.18(1 \mathrm{H}, \mathrm{dd}, J=11,4.8 \mathrm{~Hz} ; \mathrm{H}-1)$, $4.11\left(1 \mathrm{H}, \mathrm{dd}, J=11,3.5 \mathrm{~Hz} ; \mathrm{H}-1^{\prime}\right), 3.86(2 \mathrm{H}, \mathrm{d}, J=14.2 \mathrm{~Hz}, N-$ benzyl $\left.\mathrm{CH}_{2}\right), 3.68\left(2 \mathrm{H}, \mathrm{d}, J=14.2 \mathrm{~Hz}, N\right.$-benzyl $\left.\mathrm{CH}_{2}\right), 3.30(1 \mathrm{H}$, br s; OH), $3.05(1 \mathrm{H}, \mathrm{qd}, J=6.8,2.5 \mathrm{~Hz} ; \mathrm{H}-6), 1.13(3 \mathrm{H}, \mathrm{d}, J=$ $6.8 \mathrm{~Hz} ; \mathrm{H}-7), 0.90$ (9H, s; $\left.\mathrm{Me}_{3} \mathrm{CSi}\right), 0.73$ (9H, s; $\left.\mathrm{Me}_{3} \mathrm{CSi}\right), 0.12$ $(3 \mathrm{H}, \mathrm{s} ; \mathrm{MeSi}), 0.09$ (3H, s; MeSi), -0.07 (3H, s; MeSi), -0.13 $10(3 \mathrm{H}, \mathrm{s} ; \mathrm{MeSi}) ;{ }^{13} \mathrm{C}$ NMR $(125 \mathrm{MHz}) \delta 206.0,165.8,140.5$ (x 2), $129.5,18.3,18.0$ (quat C), 133.5, 130.0 (x 2), 128.5 (x 2), 128.4 (x 4), 128.1 (x 4), 126.5 (x 2), 79.9, 78.1, 75.0, 53.2 (CH), 63.3, 54.6 (х 2) $\left(\mathrm{CH}_{2}\right), 25.7$ (x 6, $\left.2 \mathrm{Me}_{3} \mathrm{CSi}\right), 8.0(\mathrm{C} 7),-4.8(\mathrm{MeSi})$, -5.1 (MeSi), -5.5 (x 2, $2 \mathrm{MeSi}$ ); HR FABMS m/z 706.3971 $15\left(\mathrm{M}+\mathrm{H}^{+}\right)$. Calcd. for $\mathrm{C}_{40} \mathrm{H}_{60} \mathrm{NO}_{6} \mathrm{Si}_{2}, 706.3959$.

\section{(2S,4R,5R,6R)-2-(Benzoyloxy)-1,4-bis-(tert-}

butyldimethylsilyloxy)--6-( $N, N$-dibenzylamino)-5-hydroxy-7phenylheptan-3-one (19b). Oil: $[\alpha]_{\mathrm{D}}+7.4$ (c 1.65; $\left.\mathrm{CHCl}_{3}\right)$; IR $v_{\max }\left(\mathrm{cm}^{-1}\right): 3430(\mathrm{br}, \mathrm{OH}), 1727$ (br, C=O); ${ }^{1} \mathrm{H}$ NMR (500 MHz) ${ }_{20} \delta 8.20(2 \mathrm{H}$, br d, $J \sim 7.5 \mathrm{~Hz}$; aromatic), $7.64(1 \mathrm{H}$, br d, $J \sim 7.5 \mathrm{~Hz}$; aromatic), $7.53(2 \mathrm{H}$, br t, $J=7.5 \mathrm{~Hz}$; aromatic), 7.30-7.00 $(15 \mathrm{H}$, br m; aromatic), $5.84(1 \mathrm{H}$, br t, $J \sim 4 \mathrm{~Hz} ; \mathrm{H}-2), 4.70(1 \mathrm{H}, \mathrm{d}, J=8$ $\mathrm{Hz}$; H-4), 4.34 (1H, br d, $J=8 \mathrm{~Hz}$; H-5), 4.26 (1H, dd, $J=10.8,4$ Hz; H-1), 4.14 (1H, dd, $J=10.8,4$ Hz; H-1'), 3.95 (2H, d, $J \sim$ $2514.7 \mathrm{~Hz}, \mathrm{~N}$-benzyl $\left.\mathrm{CH}_{2}\right), 3.60(2 \mathrm{H}$, br d, $J \sim 14.7 \mathrm{~Hz}, N$-benzyl $\left.\mathrm{CH}_{2}\right), 3.50(1 \mathrm{H}$, br s; $\mathrm{OH}), 3.22(1 \mathrm{H}$, br dd, $J \sim 10.2,4.1 \mathrm{~Hz}$; H6), 3.10 (1H, dd, $J=14.3,10.2 \mathrm{~Hz}$; H-7), 2.94 (1H, dd, $J=14.3$, $\left.4.1 \mathrm{~Hz} ; \mathrm{H}^{-7}{ }^{\prime}\right), 0.95$ (9H, s; $\left.\mathrm{Me}_{3} \mathrm{CSi}\right), 0.71$ (9H, s; $\left.\mathrm{Me}_{3} \mathrm{CSi}\right), 0.18$ (3H, s; MeSi), 0.14 (3H, s; MeSi), -0.09 (3H, s; MeSi), -0.14 $30(3 \mathrm{H}, \mathrm{s} ; \mathrm{MeSi}) ;{ }^{13} \mathrm{C}$ NMR $(125 \mathrm{MHz}) \delta 206.6,165.6,140.4,140.2$ (x 2), 129.4, 18.4, 18.1 (quat C), 133.6, 130.1, 130.0, 128.6 (x 2), 128.3 (x 4), 128.0 (x 5), 127.9 (x 3), 126.4 (x 2), 125.8, 80.1, 77.6, 71.5, $59.2(\mathrm{CH}), 63.5,54.3(\mathrm{x} 2), 31.2\left(\mathrm{CH}_{2}\right), 25.9(\mathrm{x} \mathrm{3}$, $\left.\mathrm{Me}_{3} \mathrm{CSi}\right), 25.8$ (x 3, Me $\left.{ }_{3} \mathrm{CSi}\right),-4.7(\mathrm{MeSi}),-5.0(\mathrm{MeSi}),-5.4$ 35 (MeSi) -5.5 (MeSi); HR EIMS m/z (\% rel. int.) 724.3553 $\left(\mathrm{M}^{+}-t \mathrm{Bu}, 1\right), 300$ (76), 91 (100). Calcd. for $\mathrm{C}_{46} \mathrm{H}_{63} \mathrm{NO}_{6} \mathrm{Si}_{2}-t \mathrm{Bu}$, 724.3616 .

\section{$(2 S, 4 R, 5 R, 6 R)-2-(B e n z o y l o x y)-1,4-b i s-(t e r t-$}

butyldimethylsilyloxy)-7-(tert-butyldiphenylsilyloxy)-6-( $N, N$ -

${ }_{40}$ dibenzylamino)-5-hydroxyheptan-3-one (19c). Oil: $[\alpha]_{\mathrm{D}}-6(c$ 1.3; $\left.\mathrm{CHCl}_{3}\right)$; IR $v_{\max }\left(\mathrm{cm}^{-1}\right): 3460(\mathrm{br}, \mathrm{OH}), 1725(\mathrm{br}, \mathrm{C}=\mathrm{O}) ;{ }^{1} \mathrm{H}$ NMR (500 MHz) $\delta 8.22(2 \mathrm{H}$, br d, $J \sim 8 \mathrm{~Hz}$; aromatic), $7.80(4 \mathrm{H}$, br d, $J \sim 7.5 \mathrm{~Hz}$; aromatic), 7.70-7.20 (19H, br m; aromatic), 5.94 $(1 \mathrm{H}$, br t, $J \sim 4.5 \mathrm{~Hz}$; H-2), 4.58 (2H, m; H-4/H-5), 4.22 (2H, m; $\left.{ }_{45} \mathrm{H}-1 / \mathrm{H}-1^{\prime}\right), 4.17(1 \mathrm{H}, \mathrm{dd}, J=11.5,6 \mathrm{~Hz} ; \mathrm{H}-7), 4.08(1 \mathrm{H}, \mathrm{dd}, J=$ 11.5, $4 \mathrm{~Hz}$; H-7'), 3.97, 3.93 (4H, AB system, $J=14.5 \mathrm{~Hz}, 2 \mathrm{~N}-$ benzyl $\left.\mathrm{CH}_{2}\right), 3.60(1 \mathrm{H}$, br s; OH), $3.25(1 \mathrm{H}, \mathrm{m} ; \mathrm{H}-6), 1.18(9 \mathrm{H}, \mathrm{s}$; $\left.\mathrm{Me}_{3} \mathrm{CSi}\right), 0.95$ (9H, s; $\left.\mathrm{Me}_{3} \mathrm{CSi}\right), 0.80\left(9 \mathrm{H}, \mathrm{s} ; \mathrm{Me}_{3} \mathrm{CSi}\right), 0.17(3 \mathrm{H}$, s; MeSi), 0.14 (3H, s; MeSi), $-0.01(3 \mathrm{H}, \mathrm{s} ; \mathrm{MeSi}),-0.12(3 \mathrm{H}, \mathrm{s}$; $\left.{ }_{50} \mathrm{MeSi}\right) ;{ }^{13} \mathrm{C}$ NMR $(125 \mathrm{MHz}) \delta 205.4,165.7,140.1$ (x 2), 132.9, $132.8,129.7,19.0,18.3,18.1$ (quat C), 135.7 (x 4), 133.3, 130.0 (x 4), 128.4 (x 4), 128.1 (x 4), 127.6 (x 4), 126.5 (x 4), 79.8, 78.2, 74.0, $58.9(\mathrm{CH}), 62.8,62.2,55.3(\mathrm{x} 2)\left(\mathrm{CH}_{2}\right), 26.9$ (x 3, Me $\left.{ }_{3} \mathrm{CSi}\right)$, 25.8 (x 6, $\left.2 \mathrm{Me}_{3} \mathrm{CSi}\right),-4.8(\mathrm{MeSi}),-4.9(\mathrm{MeSi}),-5.4$ (х 2) $55(\mathrm{MeSi})$; HR ESMS $\mathrm{m} / \mathrm{z} 960.5086 \quad\left(\mathrm{M}+\mathrm{H}^{+}\right)$. Calcd. for $\mathrm{C}_{56} \mathrm{H}_{78} \mathrm{NO}_{7} \mathrm{Si}_{3}, 960.5087$.

\section{$(2 S, 4 R, 5 R, 6 S)-2-(B e n z o y l o x y)-1,4-b i s-(t e r t-$}

\section{butyldimethylsilyloxy)-6-( $N, N$-dibenzylamino)-5-}

hydroxyheptan-3-one (20a). Oil: $[\alpha]_{\mathrm{D}}+35.1$ (c 2.25; $\left.\mathrm{CHCl}_{3}\right)$; IR ${ }_{60} v_{\max }\left(\mathrm{cm}^{-1}\right): 3420$ (br, OH), 1724 (br, C=O); ${ }^{1} \mathrm{H}$ NMR (500 MHz) $\delta 8.11(2 \mathrm{H}$, br d, $J \sim 7.5 \mathrm{~Hz}$; aromatic), $7.58(1 \mathrm{H}$, br t, $J \sim 7.5 \mathrm{~Hz}$; aromatic), $7.46(2 \mathrm{H}$, br t, $J \sim 7.5 \mathrm{~Hz}$; aromatic), 7.30-7.20 $(10 \mathrm{H}$, br m; aromatic), $5.97(1 \mathrm{H}$, br t, $J \sim 4 \mathrm{~Hz} ; \mathrm{H}-2), 4.60(1 \mathrm{H}$, br s; $\mathrm{H}-$ 4), $4.20(1 \mathrm{H}$, br s; OH), $4.18(1 \mathrm{H}, \mathrm{dd}, J=11.3,5 \mathrm{~Hz} ; \mathrm{H}-1), 4.09$ ${ }_{65}(1 \mathrm{H}, \mathrm{dd}, J=11.3,2.7 \mathrm{~Hz}$; H-1'), $4.02(1 \mathrm{H}, \mathrm{br} \mathrm{d}, J=9.5 \mathrm{~Hz} ; \mathrm{H}-5)$, $3.77\left(2 \mathrm{H}, \mathrm{d}, J=13.2 \mathrm{~Hz}, N\right.$-benzyl $\left.\mathrm{CH}_{2}\right), 3.30(2 \mathrm{H}, \mathrm{d}, J=13.2$ $\mathrm{Hz}, N$-benzyl $\left.\mathrm{CH}_{2}\right), 2.94(1 \mathrm{H}, \mathrm{dq}, J=7.5,6.8 \mathrm{~Hz} ; \mathrm{H}-6), 0.97(3 \mathrm{H}$, d, $J=6.8 \mathrm{~Hz} ; \mathrm{H}-7), 0.85$ (9H, s; $\left.\mathrm{Me}_{3} \mathrm{CSi}\right), 0.83$ (9H, s; $\mathrm{Me}_{3} \mathrm{CSi}$ ), 0.06 (6H, s; $2 \mathrm{MeSi}), 0.02$ (3H, s; MeSi), $-0.28(3 \mathrm{H}, \mathrm{s} ; \mathrm{MeSi}) ;{ }^{13} \mathrm{C}$ $70 \mathrm{NMR}(125 \mathrm{MHz}) \delta 204.8,165.5,138.9$ (x 2), 129.8, 18.2 (x 2) (quat C), 133.2, 129.9 (x 2), 129.2 (x 4), 128.4 (x 4), 128.3 (x 2), 127.7 (x 2), 79.8, 77.9, 72.5, 55.0 (CH), 62.5, $53.4(\mathrm{x} \mathrm{2})\left(\mathrm{CH}_{2}\right)$, 25.9 (x 3, Me ${ }_{3} \mathrm{CSi}$ ), 25.7 (x 3, Me $3 \mathrm{CSi}$ ), 8.5 (C7), -4.6 (x 2, 2 $\mathrm{MeSi}),-5.4$ (x 2, $2 \mathrm{MeSi})$; HR FABMS $\mathrm{m} / \mathrm{z} 706.3947\left(\mathrm{M}+\mathrm{H}^{+}\right)$. ${ }_{75}$ Calcd. for $\mathrm{C}_{40} \mathrm{H}_{60} \mathrm{NO}_{6} \mathrm{Si}_{2}, 706.3959$.

\section{(2S,4R,5R,6S)-2-(Benzoyloxy)-1,4-bis-(tert-}

butyldimethylsilyloxy)-6-( $N, N$-dibenzylamino)-5-hydroxy-7phenylheptan-3-one (20b). Oil: $[\alpha]_{\mathrm{D}}+14.4\left(\mathrm{c} 1 ; \mathrm{CHCl}_{3}\right)$; IR $v_{\max }$ $\left(\mathrm{cm}^{-1}\right): 3370$ (br, OH), 1724 (br, C=O); ${ }^{1} \mathrm{H}$ NMR (500 MHz) $\delta$ ${ }_{80} 8.16$ (2H, br d, $J \sim 7.5 \mathrm{~Hz}$; aromatic), $7.62(1 \mathrm{H}$, br d, $J \sim 7.5 \mathrm{~Hz}$; aromatic), $7.48(2 \mathrm{H}$, br t, $J=7.5 \mathrm{~Hz}$; aromatic), $7.40(4 \mathrm{H}, \mathrm{m}$; aromatic), 7.30-7.10 (11H, br m; aromatic), $5.95(1 \mathrm{H}$, br t, $J \sim 4$ Hz; H-2), 4.74 (1H, d, J=2 Hz; H-4), 4.50 (1H, br s; OH), 4.20 $(1 \mathrm{H}, \mathrm{dd}, J=11.3,5.3 \mathrm{~Hz} ; \mathrm{H}-1), 4.15(1 \mathrm{H}, \mathrm{dd}, J=11.3,3 \mathrm{~Hz} ; \mathrm{H}-$ $\left.{ }_{85} 1^{\prime}\right), 4.00(1 \mathrm{H}, \mathrm{dd}, J=9.5,2 \mathrm{~Hz}$; H-5), $3.75(2 \mathrm{H}$, br d, $J \sim 13 \mathrm{~Hz}$, $N$-benzyl $\left.\mathrm{CH}_{2}\right), 3.41(1 \mathrm{H}$, br td, $J \sim 9.5,3 \mathrm{~Hz}$; H-6), $3.33(2 \mathrm{H}$, br d, $J \sim 13 \mathrm{~Hz}, N$-benzyl $\left.\mathrm{CH}_{2}\right), 2.86(1 \mathrm{H}, \mathrm{dd}, J=14,3 \mathrm{~Hz} ; \mathrm{H}-7)$, $2.78\left(1 \mathrm{H}, \mathrm{dd}, J=14,10 \mathrm{~Hz} ; \mathrm{H}-7^{\prime}\right), 0.92\left(9 \mathrm{H}, \mathrm{s} ; \mathrm{Me}_{3} \mathrm{CSi}\right), 0.88$ (9H, s; $\left.\mathrm{Me}_{3} \mathrm{CSi}\right), 0.12$ (3H, s; MeSi), 0.09 (3H, s; MeSi), 0.05 ${ }_{90}(3 \mathrm{H}, \mathrm{s} ; \mathrm{MeSi}),-0.10$ (3H, s; MeSi); ${ }^{13} \mathrm{C}$ NMR $(125 \mathrm{MHz}) \delta$ 205.3, 165.4, 140.2, 139.0 (x 2), 129.6, 18.3, 18.2 (quat C), 133.1, 130.0 (x 2), 129.7 (x 2), 129.2 (x 4), 128.4 (x 2), 128.3 (x 2), $128.2(\mathrm{x} 4), 127.1$ (x 2), 126.3, 79.9, 78.0, 72.0, 61.0 (CH), 62.6, 54.1 (x 2), $33.9\left(\mathrm{CH}_{2}\right), 25.9$ (x 3, Me $\left.{ }_{3} \mathrm{CSi}\right), 25.7$ (x 3, $\left.{ }_{95} \mathrm{Me}_{3} \mathrm{CSi}\right),-4.8$ (MeSi), -5.1 (MeSi), -5.5 (x 2, $\left.2 \mathrm{MeSi}\right)$; HR EIMS m/z (\% rel. int.) $724.3692\left(\mathrm{M}^{+}-t \mathrm{Bu}, 9\right), 300$ (32), 91 (100). Calcd. for $\mathrm{C}_{46} \mathrm{H}_{63} \mathrm{NO}_{6} \mathrm{Si}_{2}-t \mathrm{Bu}, 724.3616$.

\section{(2S,4R,5R,6S)-2-(Benzoyloxy)-1,4-bis-(tert-}

\section{butyldimethylsilyloxy)-7-(tert-butyldiphenylsilyloxy)-6-( $N, N$ -} ${ }_{00}$ dibenzylamino)-5-hydroxyheptan-3-one (20c). Oil: $[\alpha]_{\mathrm{D}}-2(c$ 1.1; $\left.\mathrm{CHCl}_{3}\right)$; IR $v_{\max }\left(\mathrm{cm}^{-1}\right): 3460(\mathrm{br}, \mathrm{OH}), 1726(\mathrm{br}, \mathrm{C}=\mathrm{O}) ;{ }^{1} \mathrm{H}$ NMR (500 MHz) $\delta 8.08(2 \mathrm{H}$, br d, $J \sim 8 \mathrm{~Hz}$; aromatic), $7.72(4 \mathrm{H}$, br d, $J \sim 7 \mathrm{~Hz}$; aromatic), $7.58(1 \mathrm{H}$, br t, $J=7.5 \mathrm{~Hz}$; aromatic), 7.50-7.40 (8H, br m; aromatic), 7.20-7.10 (10H, br m; aromatic), $1055.76(1 \mathrm{H}$, br t, $J \sim 4 \mathrm{~Hz}$; H-2), $4.47(1 \mathrm{H}$, br d, $J \sim 2.5 \mathrm{~Hz}$; H-4), 4.40 (1H, br s; OH), 4.10-4.00 (2H, m; H-1/H-1'), 3.91 (1H, dd, $J$ $=11.2,3.3 \mathrm{~Hz}$; H-7), $3.83\left(1 \mathrm{H}, \mathrm{m} ; \mathrm{H}^{\prime} 7^{\prime}\right), 3.82(2 \mathrm{H}, \mathrm{d}, J=13.2$ $\mathrm{Hz}, N$-benzyl $\left.\mathrm{CH}_{2}\right), 3.70(1 \mathrm{H}, \mathrm{dd}, J=8.8,2.7 \mathrm{~Hz} ; \mathrm{H}-5), 3.63(2 \mathrm{H}$, d, $J=13.2 \mathrm{~Hz}, N$-benzyl $\left.\mathrm{CH}_{2}\right), 3.16(1 \mathrm{H}$, br td, $J=8.8,3.3 \mathrm{~Hz}$; $\left.{ }_{110} \mathrm{H}-6\right), 1.16\left(9 \mathrm{H}, \mathrm{s} ; \mathrm{Me}_{3} \mathrm{CSi}\right), 0.80\left(9 \mathrm{H}, \mathrm{s} ; \mathrm{Me}_{3} \mathrm{CSi}\right), 0.75(9 \mathrm{H}, \mathrm{s}$; $\left.\mathrm{Me}_{3} \mathrm{CSi}\right), 0.00$ (3H, s; MeSi), -0.04 (3H, s; MeSi), -0.06 (3H, s; $\mathrm{MeSi}),-0.27$ (3H, s; MeSi); ${ }^{13} \mathrm{C}$ NMR (125 MHz) $\delta 205.0,165.2$, 139.3 (x 2), 133.1 (x 2), 129.9, 19.2, 18.2, 18.1 (quat C), 136.0 (x 2), 135.9 (x 2), 130.0 (x 3), 129.8, 129.2 (x 4), 128.4 (x 4), 128.3 
(x 3), 127.7 (x 4), 127.1 (x 2), 79.3, 78.5, 68.8, 60.8 (CH), 62.5, 62.3, 54.8 (x 2) $\left(\mathrm{CH}_{2}\right), 27.2$ (x 3, Me $\left.e_{3} \mathrm{CSi}\right), 25.8$ (x 3, Me $\left.{ }_{3} \mathrm{CSi}\right)$, 25.7 (x 3, $\left.\mathrm{Me}_{3} \mathrm{CSi}\right),-4.8$ (MeSi), -4.9 (MeSi), -5.4 (x 2) (MeSi); HR FABMS $\mathrm{m} / \mathrm{z} 960.5054\left(\mathrm{M}+\mathrm{H}^{+}\right)$. Calcd. for $\mathrm{C}_{56} \mathrm{H}_{78} \mathrm{NO}_{7} \mathrm{Si}_{3}$, ${ }_{5} 960.5087$.

\section{Acknowledgments}

Financial support has been granted by the Spanish Ministry of Science and Technology (projects CTQ2005-06688-C02-01 10 and CTQ2005-06688-C02-02), by the BANCAJA-UJI foundation (projects P1-1A-2005-15 and P1-1B-2005-30) and by the Conselleria de Educación, Ciencia y Empresa de la Generalitat Valenciana (project ACOMP07/023).

${ }^{a}$ Depart. de Q. Inorgánica y Orgánica, Univ. Jaume I, Castellón, E12080 Castellón, Spain. Fax: +34-964-728214; Tel: +34-964-728242; E-mail: mcarda@qio.uji.es

${ }^{b}$ Depart. de Q. Orgánica, Univ. de Valencia, E-46100 Burjassot,

20 Valencia, Spain. Fax: +34-96-3544328; Tel: +34-96-3544337; E-mail: alberto.marco@uv.es

$†$ Electronic Supplementary Information (ESI) available: Additional experimental procedures and tabulated spectral data of all correlation 25 intermediates. Graphical NMR spectra of all new compounds (three PDF files). See DOI: 10.1039/b000000x

\$ Dedicated to the memory of Prof. Dr. emerit. E. Vogel, University of Cologne, Germany, deceased March 31, 2011. 30

\section{References}

1 For reviews on aldol reactions, see: (a) D. A. Evans, J. V. Nelson and T. R. Taber, Top. Stereochem., 1982, 13, 1-115. (b) T. Mukaiyama, Org. React., 1982, 28, 203-331. (c) S. Masamune, W. Choy, J. S. Petersen and L. R. Sita, Angew. Chem. Int. Ed., 1985, 24, 1-30. (d) C. H. Heathcock in Asymmetric Synthesis, ed. J. D. Morrison, Academic Press, Orlando, 1984, Vol. 3, pp. 111-212. (e) C. H. Heathcock, Aldrichimica Acta, 1990, 23, 99-111. (f) Comprehensive Organic Synthesis, eds. B. M. Trost, I. Fleming and E. Winterfeldt, Pergamon Press, Oxford, 1993, Vol. 2. (g) H. B. Mekelburger and C. S Wilcox, in Ref. 1f, pp. 99-131. (h) C. H. Heathcock in Ref. 1f, pp. 133-179 and 181-238. (i) B. M. Kim, S. F. Williams and S Masamune in Ref. 1f, pp. 239-275. (j) M. W. Rathke and P. Weipert in Ref. 1f, pp. 277-299. (k) I. Paterson in Ref. 1f, pp. 301-319. (l) A. S. Franklin and I. Paterson, Contemp. Org. Synth. 1994, 1, 317-338. (m) M. Braun in Houben-Weyl's Methods of Organic Chemistry, Stereoselective Synthesis, eds. G. Helmchen, R. W. Hoffmann, J. Mulzer and E. Schaumann, Georg Thieme Verlag, Stuttgart, 1996, Vol. 3, pp. 1603-1666 and 1713-1735. (n) R. Mahrwald, Chem. Rev., 1999, 99, 1095-1120. (o) C. Palomo, M. Oiarbide and J. M. García, Chem. Eur. J., 2002, 8, 36-44. (p) C. Palomo, M. Oiarbide and J. M. García, Chem. Soc. Rev., 2004, 33, 65-75. (q) Modern Aldol Reactions, ed. R. Mahrwald, Wiley-VCH, Weinheim, 2004. (r) E. M. Carreira, A. Fettes and C. Marti, Org. React., 2006, 67, 1-216. (s) D. A. Evans, G. Helmchen, M. Ruping and J. Wolfgang in Asymmetric Synthesis, eds. M. Christmann and S. Bräse, Wiley-VCH, Weinheim, 2007, pp. 3-9. (t) J. Mlynarski and J. Paradowska, Chem. Soc. Rev., 2008, 37, 1502-1511. (u) L. M. Geary and P. G. Hultin, Tetrahedron:

60 Asymmetry 2009, 20, 131-173. (v) T. Brodmann, M. Lorenz, R. Schaeckel, S. Simsek and M. Kalesse, Synlett, 2009, 174-192.

2 For recent reviews on various organocatalytic processes, including aldol reactions, see: (a) G. Guillena, C. Nájera and D. J. Ramón, Tetrahedron: Asymmetry 2007, 18, 2249-2293. (b) D. Enders and A.

65 A. Narine, J. Org. Chem., 2008, 73, 7857-7870. (c) M. Gruttadauria,
F. Giacalone and R. Noto, Adv. Synth. Catal., 2009, 351, 33-57. (d) A.-N. Alba, X. Companyo, M. Viciano and R. Rios, Curr. Org. Chem., 2009, 13, 1432-1474. (e) M. Raj and V. K. Singh, Chem. Comm., 2009, 6687-6703. (f) S. G. Zlotin, A. S. Kucherenko and I. P. 70 Beletskaya, Russ. Chem. Rev., 2009, 78, 737-784. (g) C. Grondal, M Jeanty and D. Enders, Nature Chem., 2010, 2, 167-178. (h) B. M. Trost and C. S. Brindle, Chem. Soc. Rev., 2010, 39, 1600-1632.

3 Organocatalytic aldol processes may have played a key role in the origin of chirality of biomolecules during prebiotic times. See: M. Mauksch, S. Wei, M. Freund, A. Zamfir and S. B. Tsogoeva, Orig. Life Evol. Biosph., 2010, 40, 79-91. See also: C. Anastasi, F. F. Buchet, M. A. Crowe, A. L. Parkes, M. W. Powner, J. M. Smith and J. D. Sutherland, Chem. Biodivers., 2007, 4, 721-739.

4 (a) For reviews on boron aldol reactions, see: C. J. Cowden and I. 80 Paterson, Org. React., 1997, 51, 1-200. (b) A. Abiko, Acc. Chem. Res., 2004, 37, 387-395.

5 (a) J. A. Marco, M. Carda, E. Falomir, C. Palomo, M. Oiarbide, J. A. Ortiz and A. Linden, Tetrahedron Lett., 1999, 40, 1065-1068. (b) M. Carda, J. Murga, E. Falomir, F. González, Tetrahedron, 2000, 56 677-683. (c) J. Murga, E. Falomir, M. Carda and J. A. Marco, Tetrahedron: Asymmetry, 2002, 13, 2317-2327. (d) J. Murga, E. Falomir, F. González, M. Carda and J. A. Marco, Tetrahedron, 2002, 58, 9697-9707.

6 (a) Prior to our work, ${ }^{5}$ only a single precedent of formation of $Z$ 90 boron enolates of ketones with $\mathrm{Chx}_{2} \mathrm{BCl}$ had been reported: I. Paterson, D. J. Wallace and S. M. Velázquez, Tetrahedron Lett., 1994, 35, 9083-9086. (b) We have produced evidence that this phenomenon may be general with suitably protected $\alpha$-oxygenated ketones: J. Murga, E. Falomir, M. Carda, F. González and J. A. Marco, Org. Lett., 2001, 3, 901-904.

7 Other ketones structurally related to erythrulose behave in the same way: (a) M. Carda, J. Murga, E. Falomir, F. González and J. A. Marco, Tetrahedron: Asymmetry, 2000, 11, 3211-3220. (b) M. Carda, F. González, R. Sánchez and J. A. Marco, Tetrahedron: Asymmetry, 2002, 13, 1005-1010. (c) S. Díaz-Oltra, J. Murga, E. Falomir, M. Carda, G. Peris and J. A. Marco, J. Org. Chem., 2005, 70, 8130-8139.

8 J. A. Marco, M. Carda, S. Díaz-Oltra, J. Murga, E. Falomir and H. Roeper, J. Org. Chem., 2003, 68, 8577-8582.

1059 S. Díaz-Oltra, M. Carda, J. Murga, E. Falomir and J. A. Marco, Chem. Eur. J., 2008, 14, 9240-9254.

10 The same stereochemical course was also observed in aldol reactions of other ketones related to $\mathbf{1}^{7}$

11 H. E. Zimmerman and M. D. Traxler, J. Am. Chem. Soc., 1957, 79 1920-1923.

12 For theoretical studies on the transition states of boron aldol reactions, see: (a) Y. Li, M. N. Paddon-Row and K. N. Houk, J. Org. Chem., 1990, 55, 481-493. (b) J. M. Goodman, S. D. Kahn and I. Paterson, J. Org. Chem., 1990, 55, 3295-3303. (c) F. Bernardi, M. A Robb, G. Suzzi-Valli, E. Tagliavini, C. Trombini and A. UmaniRonchi, J. Org. Chem., 1991, 56, 6472-6475. (d) A. Bernardi, C. Gennari, J. M. Goodman and I. Paterson, Tetrahedron: Asymmetry, 1995, 6, 2613-2636. (e) C. Gennari, S. Ceccarelli, U. Piarulli and K. Aboutayab, J. Braz. Chem. Soc., 1998, 9, 319-326. (f) V. J. Cee, C. J. Cramer and D. A. Evans, J. Am. Chem. Soc., 2006, 128, 2920-2930. (g) J. M. Goodman and R. S. Paton, Chem. Comm., 2007, 2124-2126.

13 In all discussions in this paper, no specific differentiation is made between the purely steric Felkin-Anh model (for aldehydes bearing all-carbon substituents) and the stereoelectronic "polar Felkin-Anh" model (for aldehydes bearing $\alpha$-heteroatoms): (a) M. Chérest, $H$. Felkin and N. Prudent, Tetrahedron Lett., 1968, 9, 2199-2204. (b) N. T. Anh, Top. Curr. Chem., 1980, 88, 145-162. (c) A. Mengel and O. Reiser, Chem. Rev., 1999, 99, 1191-1223. See also: R. J. Smith, M Trzoss, M. Bühl and S. Bienz, Eur. J. Org. Chem., 2002, 2770-2775.

13014 (a) H. B. Bürgi, J. D. Dunitz and E. Shefter, J. Am. Chem. Soc., 1973, 95, 5065-5067. (b) H. B. Bürgi, J. D. Dunitz, J. M. Lehn and G. Wipff, Tetrahedron, 1974, 30, 1563-1572. (c) R. E. Gawley and J. Aubé, Principles of Asymmetric Synthesis, Pergamon, 1996, Chapters 4 and 5 .

13515 (a) J. W. Cornforth, R. H. Cornforth and K. K. Mathew, J. Chem. Soc., 1959, 112-127. For theoretical refinements of the model, see: 
(b) M. N. Paddon-Row, N. G. Rondan and K. N. Houk, J. Am. Chem. Soc., 1982, 104, 7162-7166. (c) K. N. Houk, M. N. Paddon-Row, N. G. Rondan, Y.-D. Wu, F. K. Brown, D. C. Spellmeyer, J. T. Metz, Y. Li and R. J. Longarich, Science, 1986, 231, 1108-1117.

516 M. Carda, E. Falomir, J. Murga, E. Castillo, F. González and J. A. Marco, Tetrahedron Lett., 1999, 40, 6845-6848.

17 Ketone 13 and its enantiomer have been used by other groups for the synthesis of natural products. See: (a) C. J. Forsyth, J. Hao and J. Aiguadé, Angew. Chem. Int. Ed., 2001, 40, 3663-3667. (b) A. A. Jaworski and J. D. Burch, Tetrahedron Lett., 2007, 48, 8787-8789.

18 For uses of ketone $\mathbf{1 5}$ in the synthesis of natural products, see: (a) J. Murga, P. Ruiz, E. Falomir, M. Carda, G. Peris and J. A. Marco, J. Org. Chem., 2004, 69, 1987-1992. (b) P. Ruiz, J. Murga, M. Carda and J. A. Marco, J. Org. Chem., 2005, 70, 713-716.

1519 R. W. Hoffmann, Chem. Rev., 1989, 89, 1841-1860.

20 E. P. Lodge and C. H. Heathcock, J. Am. Chem. Soc., 1987, 109, 3353-3361. The "non-Anh" label refers to transition structures in which attack takes place anti to a substituent which neither has the lowest lying $\sigma^{*}{ }_{\mathrm{C}-\mathrm{x}}$ orbital (for $\alpha$-heteroatom-substituted aldehydes) nor is the sterically bulkiest one (for aldehydes not bearing $\alpha$ heteroatoms). See also ref. ${ }^{13 \mathrm{c}}$

21 W. R. Roush, J. Org. Chem., 1991, 56, 4151-4157. The quantitative importance of the syn pentane interactions is underscored in the cases under study here by the fact that enolate $\mathbf{1}_{\mathbf{B}}$ does not react with pivalaldehyde. ${ }^{5}$ Indeed, if a TS is drawn for the aldol reaction with this aldehyde, a syn pentane interaction will always be present for all rotamers around the $t \mathrm{Bu}-\mathrm{CO}$ bond.

22 For two interesting reviews on the conformational aspects of openchain carbon backbones, see: (a) R. W. Hoffmann, M. Stahl, U.

30 Schopfer and G. Frenking, Chem. Eur. J., 1998, 4, 559-566. (b) R. W. Hoffmann, Angew. Chem. Int. Ed., 2000, 39, 2054-2070. 